\title{
Novel molecular components involved in callose-mediated Arabidopsis defense against Salmonella enterica and Escherichia coli 0157:H7
}

Paula Rodrigues Oblessuc, Cleverson Carlos Matiolli and Maeli Melotto* (1)

\begin{abstract}
Background: Food contamination with Salmonella enterica and enterohemorrhagic Escherichia coli is among the leading causes of foodborne illnesses worldwide and crop plants are associated with $>50 \%$ of the disease outbreaks. However, the mechanisms underlying the interaction of these human pathogens with plants remain elusive. In this study, we have explored plant resistance mechanisms against these enterobacteria and the plant pathogen Pseudomonas syringae pv. tomato (Pst) DC3118, as an opportunity to improve food safety.

Results: We found that $S$. enterica serovar Typhimurium (STm) transcriptionally modulates stress responses in Arabidopsis leaves, including induction of two hallmark processes of plant defense: ROS burst and cell wall modifications. Analyses of plants with a mutation in the potentially STm-induced gene EXOTOH4 revealed that its encoded protein is required for stomatal defense against STm and E. coli O157:H7, but not against Pst DC3118. In the apoplast however, EXO70H4 is required for defense against STm and Pst DC3118, but not against E. coli O157: H7. Moreover, EXO7OH4 is required for callose deposition, but had no function in ROS burst, triggered by all three bacteria. The salicylic acid (SA) signaling and biosynthesis proteins NPR1 and ICS1, respectively, were involved in stomatal and apoplastic defense, as well as callose deposition, against human and plant pathogens.

Conclusions: The results show that $\mathrm{EXO} 70 \mathrm{H} 4$ is involved in stomatal and apoplastic defenses in Arabidopsis and suggest that EXO70H4-mediated defense play a distinct role in guard cells and leaf mesophyll cells in a bacteriadependent manner. Nonetheless, $\mathrm{EXO} 7 \mathrm{OH} 4$ contributes to callose deposition in response to both human and plant pathogens. NPR1 and ICS1, two proteins involved in the SA signaling pathway, are important to inhibit leaf internalization and apoplastic persistence of enterobacteria and proliferation of phytopathogens. These findings highlight the existence of unique and shared plant genetic components to fight off diverse bacterial pathogens providing specific targets for the prevention of foodborne diseases.
\end{abstract}

Keywords: Salmonella enterica, Shiga toxin-producing Escherichia coli, Pseudomonas syringae, Arabidopsis mutants, Callose deposition, MAMP-triggered immunity

\footnotetext{
* Correspondence: melotto@ucdavis.edu

Department of Plant Sciences, University of California, One Shields Avenue,

Davis, CA 95616, USA
}

(c) The Author(s). 2020 Open Access This article is distributed under the terms of the Creative Commons Attribution 4.0 International License (http://creativecommons.org/licenses/by/4.0/), which permits unrestricted use, distribution, and reproduction in any medium, provided you give appropriate credit to the original author(s) and the source, provide a link to the Creative Commons license, and indicate if changes were made. The Creative Commons Public Domain Dedication waiver (http://creativecommons.org/publicdomain/zero/1.0/) applies to the data made available in this article, unless otherwise stated. 


\section{Background}

Foodborne diseases caused by human pathogens have profound social and economic impacts. Despite several safety measures taken to prevent disease outbreaks, it is estimated that 600 million (1 in 10) people are affected worldwide every year [1]. According to the US Foodborne Disease Outbreak Surveillance System (FDOSS), there were 972 outbreaks associated with raw produce during 1998-2013 in the US, resulting in 34,674 illnesses events, 2315 hospitalizations, and 72 deaths [2]. The most common etiologic agents identified in these foodborne disease outbreaks were norovirus (54\%), Salmonella enterica (21\%) and Shiga toxin-producing Escherichia coli (10\%) [2]. Therewith, the US Food Safety Modernization Act (FSMA) was established in 2011, seeking to change the food safety system by shifting the focus from foodborne illness response to disease prevention. Thus, it is imperative to understand the biological processes involved in the human bacterial pathogenplant interactions to prevent, or at least minimize, enteropathogen colonization of fresh produce.

It has been previously thought that plants could be passive vectors for human pathogens. However, recent studies support the hypothesis that S. enterica and enterohemorrhagic E. coli are capable of colonizing plant tissues and plants can activate immune responses upon bacterial colonization [3-23]. These bacteria are able to survive in the leaf apoplast of a wide range of plant species, including cilantro (Coriandrum sativum), lettuce (Lactuca sativa L.), Arabidopsis thaliana, tomato (Solanum lycopersicum), spinach (Spinacia oleracea), Nicotiana benthamiana, and basil (Ocimum basilicum) [6, 11, 22, 24-29]. Once inside the leaf apoplast, these bacteria remain protected from common sanitation treatments of edible leaves [30, 31], posing a risk to reach their human host.

Endophytic survival of bacterial pathogens of humans seems to be regulated by the plant immune system reviewed by [32-34]. Microbe-associated molecular patterns (MAMPs), such as the motor protein flagellin in bacteria [35], can induce plant basal defenses known as MAMP-Triggered Immunity (MTI) [36]. For instance, Seflg22, a 22 amino acid-peptide derived from the $S$. enterica serovar Typhimurium (STm) flagellin, is perceived by Arabidopsis, Nicotiana benthamiana, tomato, and Medicago truncatula [23, 37, 38], and the E. coli flagellin-derived peptide flg15. ${ }^{\text {coli }}$ is biologically active in tomato, spinach, and Arabidopsis plants [15, 18, 39-41]. Moreover, STm and E. coli O157:H7 induce stomatal closure, a well-known MTI response, in several plant species [17, 22, 42] and lead to MTI-associated transcriptional changes in plants $[15,32,38,43-45]$. In fact, a large set of Arabidopsis genes is regulated by $E$. coli O157:H7 in a flagellin-dependent manner, evidenced by comparative transcriptome analysis between the wild type and a fls 2 mutant (deficient in flagellin perception) inoculated with E. coli $\mathrm{O} 157: \mathrm{H} 7$ or the E. coli flagellin deficient mutant TUV86-2 fliC [43, 45]. Overall, these studies indicate that both STm and E. coli induce MTI in plants, although the mechanisms downstream of enterobacterium perception are still elusive.

In this study, we explored the plant transcriptional modulation mediated by STm and used Arabidopsis genetic resources to again insights on the molecular mechanisms activated during plant colonization with STm and E. coli O157:H7. Additionally, we sought to establish correlations with the model system ArabidopsisPseudomonas syringae pv. tomato (Pst). We demonstrate that EXO70H4 (EXOCYST SUBUNIT EXO70 FAMILY PROTEIN H4) participates in the stomatal defense in response to both enterobacteria, while in the leaf apoplast it is involved in the immune response only against STm and Pst. Therefore, EXO70H4 seems to function in a bacterium-specific manner, depending on the plant cell type. Moreover, we show that plant basal defense against STm 14,028 s, E. coli O157:H7, and Pst DC3118 require the salicylic acid (SA) biosynthesis and signaling proteins ICS1 (ISOCHORISMATE SYNTHASE 1) and NPR1 (NON-EXPRESSER OF PATHOGENESIS-RELATED GENE 1), respectively. Interestingly, EXO70H4, ICS1, and NPR1 contribute to leaf callose deposition in response to all of these bacteria. Our results indicate that EXO70H4 is a novel component of plant defense against pathogens. Additionally, we demonstrate that SAmediated immunity is a common plant defense response to both entero- and phyto-bacteria that involves the induction of callose deposition through EXO70H4. These findings represent an advancement of our current understanding of the plant genetic mechanisms that ultimately protect leaves against successful bacterial colonization.

\section{Results \\ Global gene expression analysis reveals plant processes modulated by STm in Arabidopsis}

To identify specific genetic mechanism of Arabidopsis defenses towards STm persistence, we performed a transcriptomic analysis of leaves inoculated with the STm strain SL1344 using the Affymetrix GeneChip ATH1 (Thermo Scientific, Rockford, IL). Z-ratio normalization of array intensity data [46] showed a normal distribution of relative gene expression (STm- versus mock-treated samples) and revealed the significant differentially expressed genes within the $2 \%$ extremes of the bell curve (Additional file 1). Linear regression between gene expression calculated as Z-ratio and $\log _{2}$ fold changes showed a high correlation $\left(R^{2}=0.9676\right)$ (Additional file 1 ), where both extreme Z-ratio values coincided with both extreme $\log _{2}$ fold change values. Using these two 
methods to calculate relative gene expression, we identified 585 differentially expressed genes, in which 310 were up-regulated and 275 were down-regulated upon STm SL1344 inoculation (Additional file 2; ID NASCAR RAYS-674). To increase the confidence for the identification of differentially expressed genes, we validated the microarray analysis using Reverse Transcriptasequantitative PCR (RT-qPCR). The relative expression level of nine randomly selected genes from the microarray dataset (four up-regulated, three non-regulated, and two down-regulated; Additional file 2) showed the same expression patterns calculated by RT-qPCR (Additional file 3), indicating that the microarray analysis is robust enough for calling differentially expressed genes.

Gene Ontology (GO) single enrichment analysis (SEA) of genes differentially regulated by STm SL1344 allowed the identification of metabolic processes modulated in bacterium-inoculated samples. We identified 144 and 25 GO terms significantly more abundant $(\mathrm{FDR} p<0.05)$ in the up-regulated and down-regulated gene sets, respectively, as compared to the Arabidopsis reference gene model available at TAIR10 (Arabidopsis.org) (Additional file 4). Eleven GO terms were significantly enriched in both up- and downregulated gene sets (Fig. 1a). Among them, two are parental terms, 'multi-organism process' and 'response to stimulus', and the other nine are child terms of the latter (Additional file 5). This suggest that STm SL1344 modulated plant stress responses.

GO terms exclusively associated with up-regulated genes support the hypothesis of activation of defense responses by STm SL1344 in Arabidopsis leaves (Additional file 4). Among them, the GO terms 'response to oxidative stress' and 'response to hydrogen peroxide' indicate that STm SL1344 can induce reactive oxygen species (ROS) burst, a well-known immune response in plants. In addition, the GO terms 'cell periphery', 'plasma membrane', 'external encapsulating structure' and 'cell wall' were enriched categories exclusively present in the STm SL1344-induced genes dataset, suggesting that this bacterium triggers cell wall modifications in Arabidopsis.

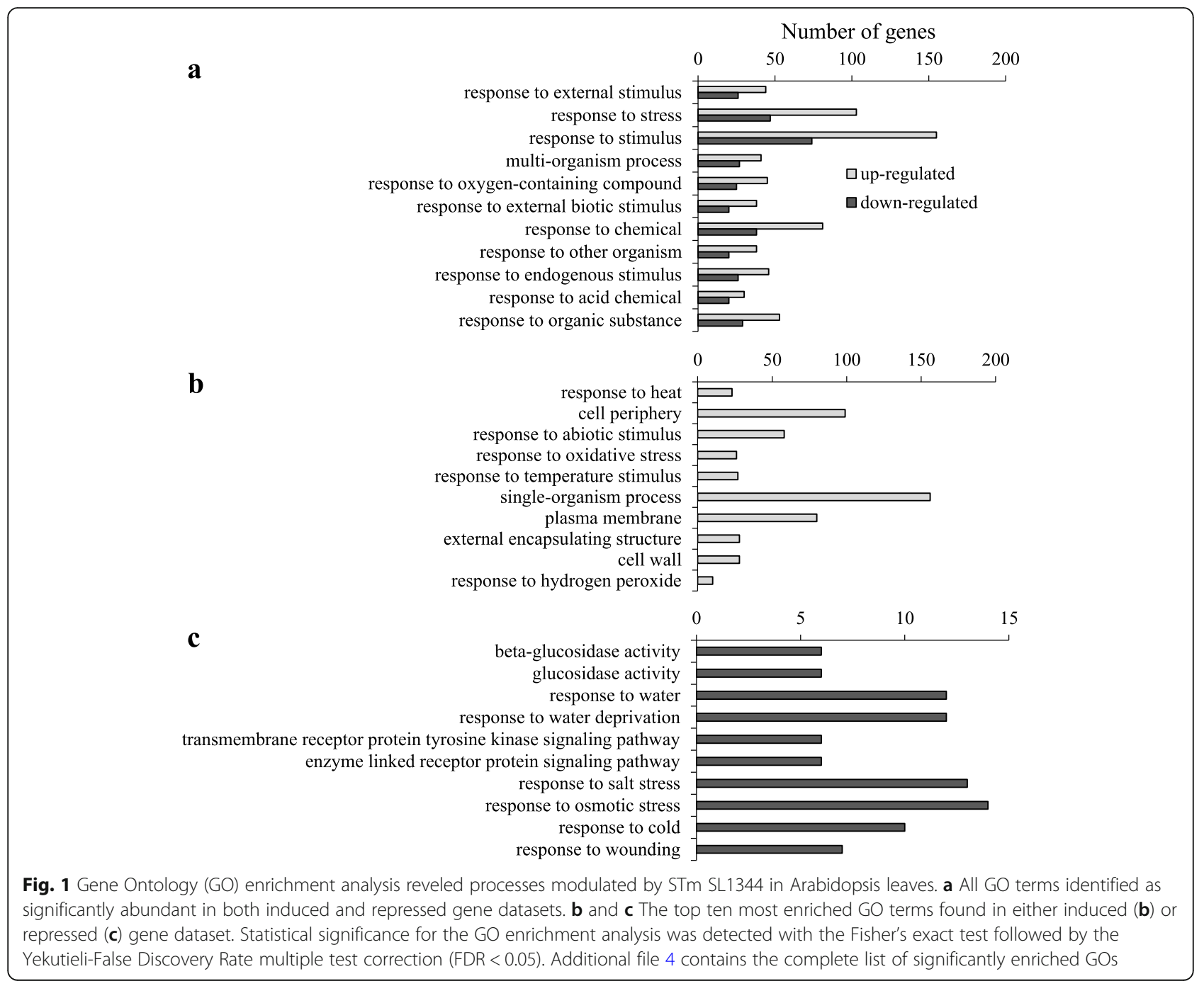


Interestingly, 'response to heat' and 'response to temperature stimulus' were also among the up-regulated enriched GO terms, which include several heat shock proteins (Fig. 1b; Additional file 4). These proteins function as molecular chaperones and play an important role in the quality control of protein receptors at the plasma membrane during plant-microbe interaction [47].

We also identified GO terms that are exclusively overrepresented in the STm SL1344 down-regulated gene dataset (Additional file 4). Among them, the 'beta-glucosidase activity' and 'glucosidase activity' categories (Fig. 1c) indicate that STm SL1344 down-regulates the hydrolysis of glucosyl compounds. Moreover, the GO terms 'response to water', 'response to water deprivation', 'response to salt stress', and 'response to osmotic stress' suggest that STm SL1344 repress drought and salt stress responses in Arabidopsis. The GO term 'response to cold' (Fig. 1c) covers genes mainly related to glycosyl hydrolysis and drought/salt stress responses (Additional file 4), reinforcing the down-regulation of these plant responses by STm SL1344. Furthermore, two GO terms related to signal transduction, 'transmembrane receptor protein tyrosine kinase signaling pathway' and 'enzyme linked receptor protein signaling pathway', were enriched within the down-regulated genes, covering six leucine-rich repeat protein kinases related to plant development.

Overall, we can conclude that STm SL1344 causes transcriptional modulations in Arabidopsis leaves, affecting plant innate immune responses and cell growth, mainly by the induction of ROS burst and cell wall modifications, as well as by repressing glucosyl compounds hydrolysis, drought and salt stress responses, and signaling responses mediated by developmental-related receptors.

\section{$\mathrm{EXO70H4}$ is a novel protein that contribute to both stomatal- and apoplast-based defense in a bacterium- specific manner}

Transcriptome analysis revealed that STm SL1344 induces the EXO7OH4 gene (Additional file 2). Therefore, we evaluated the possible role of EXO70H4 in the Arabidopsis interaction with STm, as well as with E. coli O157:H7 and Pst DC3118. For these experiments, we used the exo70h4-3 mutant that has a T-DNA insertion in the coding sequence of the $E X O 7 O H 4$ gene leading to the synthesis of a truncated mRNA (Additional file 6) [48];. This mutant plant had a defective stomatal closure only after inoculation with the human pathogens STm 14,028 s and E. coli O157:H7 (Fig. 2a). All three bacterial induced a significant reduction in the in the average stomatal aperture width in both Col-0 and exo70h4-3 plants (Additional file 7). We also evaluated the bacterial population dynamics in leaves of the exo70h4-3 mutant and observed that Pst DC3118 population was higher than that of Col-0 only in the first day after inoculation (DAI), whereas the STm 14,028 s population persisted at a high level at the third DAI (Fig. 2b). The EXO70H4mediated apoplastic defense seems to be bacterium specific, as E. coli O157:H7 showed same level of survival inside exo70h4-3 leaves in comparison to Col-0 (Fig. 2b). Therewith, EXO70H4 may have a function in the guard cell response specifically to enterobacteria, whereas in the leaf mesophyll, EXO70H4 activity may be important for defense against Pst DC3118 and STm 14, $028 \mathrm{~s}$, but not against E. coli O157:H7.

\section{EXO70H4 contributes to bacterium-induced callose deposits, but not ROS burst}

We have found that STm SL1344 transcriptionally modulates 'cell wall' processes in Arabidopsis leaf (Fig. 1b)
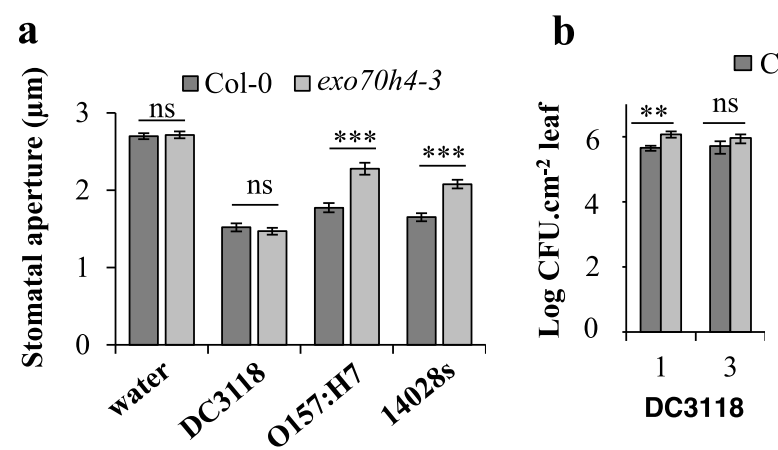

$\square$ Col-0 $\square$ exo $70 h 4-3$
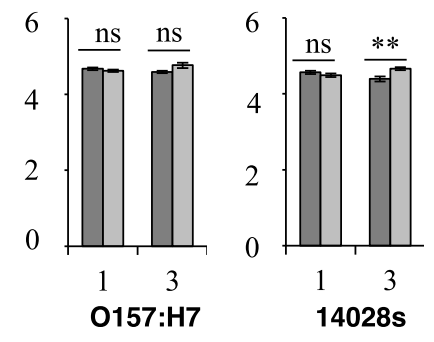

Fig. $2 \mathrm{EXO} 70 \mathrm{H} 4$ contribute to both stomatal- and apoplast-based defense in a bacterium-specific manner. a Stomatal aperture width in Arabidopsis leaves was measured at $2 \mathrm{~h}$ post inoculation with Pst DC3118, E. coli O157:H7, or STm 14,028 s at a concentration of $1 \times 10^{8}$ CFU.mL ${ }^{1}$. Results are shown as mean of two independent biological replicates $(n=120 \pm$ SE). $\mathbf{b}$ Bacterial population was evaluated at one and three days after vacuum-inoculation with Pst DC3118, E. coli O157:H7, or STm 14,028 s at a concentration of $1 \times 10^{6} \mathrm{CFU}_{\mathrm{mL}} \mathrm{mL}^{-1}$. Results are shown as the average of two independent biological replicates $(n=12 \pm$ SE). Note that human bacterial growth within plants is very consistent as reflected by the small error bars. Statistical difference between means (mutant versus Col-0) was detected with two-tailed Student's t-test $\left(* *=p<0.01 ;{ }^{* * *}=\right.$ $p<0.001 ; \mathrm{ns}=$ non-significant). CFU = colony forming unit 
and EXO70H4 was shown previously to participate on the callose deposition on leaf trichomes [48]. As callose deposition is a hallmark plant basal immune response to pathogens reviewed by [49], we assessed the extent of callose production in the exo70h4-3 mutant after bacterial inoculation. Reduced callose deposition was observed in exo70h4-3 as compared to Col-0 after inoculation with any of the three bacteria (Fig. 3a), suggesting that $\mathrm{EXO} 70 \mathrm{H} 4$ contributes to the formation of callose in leaves under biotic stress.

ROS burst is another hallmark of plant basal defense response [50], and our transcriptome analysis revealed that STm modulates plant 'response to oxygen-containing compounds', inducing 'response to oxidative stress' and 'response to hydrogen peroxide' (Fig. 1). Therefore, we measured bacterium-induced ROS production in leaves of Col-0 and exo70h4-3 mutant plants to verify whether ROS could contribute to the enhanced susceptibility observed in exo70h4-3 plants (Fig. 2b). Mock-treated leaves did not show a ROS burst (Fig. 3b), whereas all three bacteria induced similar level of ROS in both Col-0 and exo70h4-3 (Fig. 3b). These findings indicate that, although both enterics and the phytopathogen activate this plant defense, $\mathrm{EXO} 70 \mathrm{H} 4$ has no role in this process.

\section{Defense against human pathogens, similar to plant pathogens, requires the SA signaling components ICS1 and NPR1}

Plant defense to bacteria, including callose biosynthesis, is known to require a functional SA pathway reviewed by [49]. Thus, we evaluated plants with impaired SA biosynthesis through a mutation in the ICS1 gene, sid2-2 [51], and SA signaling through a mutation in the NPR1 gene, npr1-1 [52]. Homozygosity in the sid2-2 and npr 1-1 plant lines were confirmed by PCR (Additional file 6). Pst DC3118, E. coli O157:H7, and STm 14,028 s did not induce stomatal closure in sid2-2 and npr1-1 mutants to the same extent as they did in Col-0 plants (Fig. 4a); although all three bacteria induced a significant stomatal closure in Col-0, sid2-2, and npr1-1 as compared to the water control (Additional file 7), indicating that stomatal immunity is not completely abolish in these mutants. Interestingly, the water-treated mutant leaves had a significantly wider stomatal aperture width

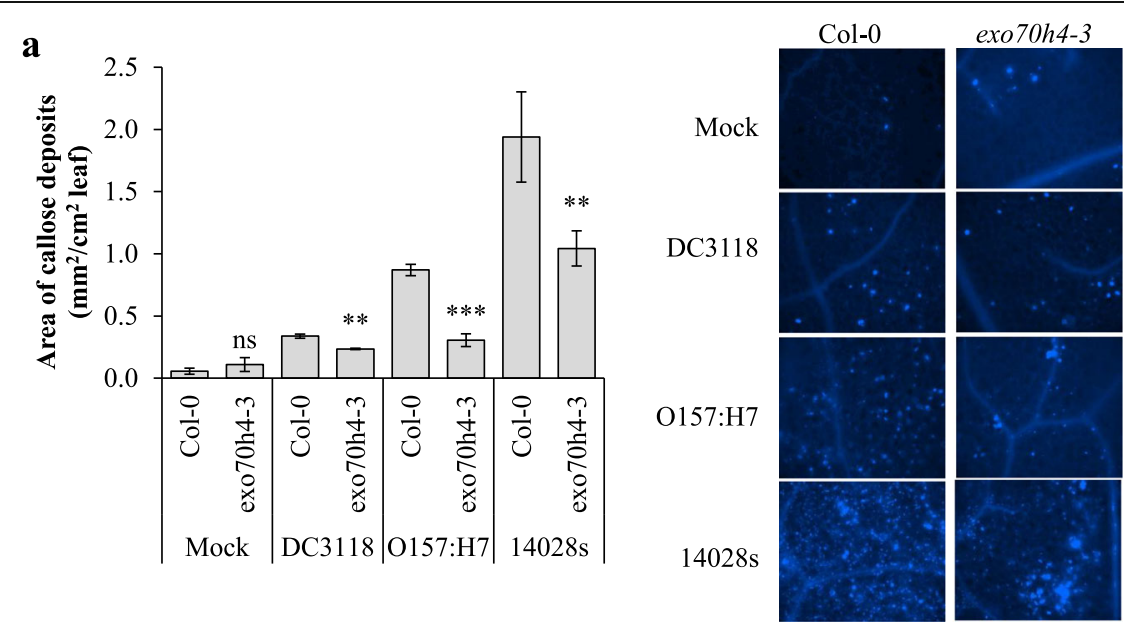

b

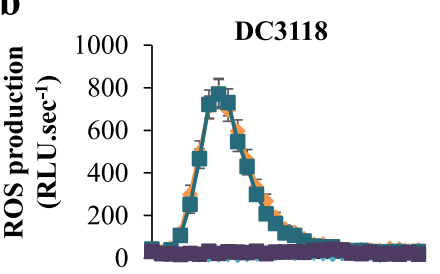

$1020 \quad 30 \quad 40 \quad 50$

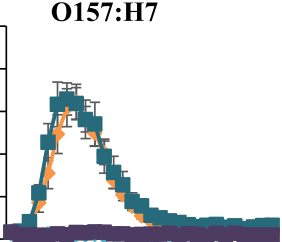

$1020 \quad 30 \quad 40 \quad 50$

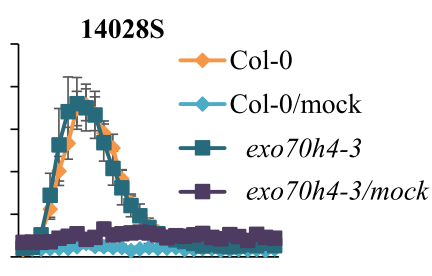

$10203040 \quad 50$

Fig. $3 \mathrm{EXO} 7 \mathrm{OH} 4$ contributes to bacterium-induced callose deposits, but not ROS burst. a Callose deposits area was measured in each genotype after four- to five-week-old plants were syringe-infiltrated water as a mock control or with $1 \times 10^{8}$ CFU.mL ${ }^{-1}$ of Pst DC3118, STm 14,028 s, or E. coli O157:H7. Results are shown as average of three to four biological replicate ( $n=18$ to $37 \pm$ SE) and the experiment was repeated twice with similar results. Statistical difference between the means (wild type versus mutant plant) was calculated using the two-tailed Student's $t$-test ${ }^{* *}=p<0.01$; ${ }^{* * *}=p<0.001 ; \mathrm{ns}=$ non-significant). The pictures on the left are representative of each plant genotype per treatment. $\mathbf{b}$ Leaf discs of four- to five-week-old plants were incubated with control solution or $1 \times 10^{8} \mathrm{CFU} \cdot \mathrm{mL}^{-1}$ of boiled Pst DC3118, STm 14,028 S, or E. coli O157:H7. Results are shown as the average of luminescence per genotype in three independent biological replicates $(n=21$ to $37 \pm$ SE). Luminescence was recorded over 60 min using a Synergy ${ }^{\text {TM }} \mathrm{H} 1$ microplate reader and the Biotek Gen5 (Biotek) software. RLU = Relative Light Units 


\section{a}
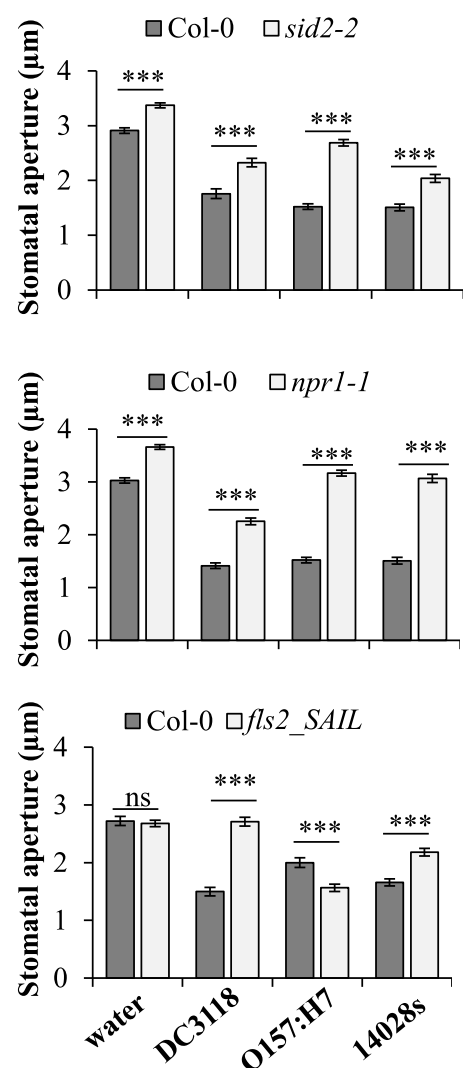

b

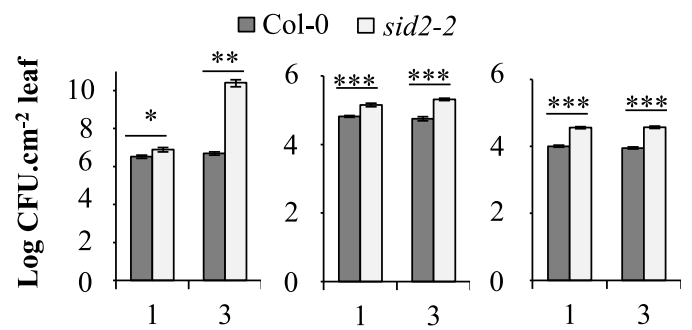

$\square$ Col-0 $\square$ nprl-1

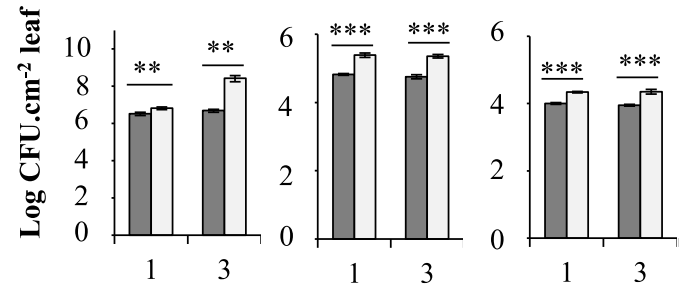

$\square$ Col-0 $\square$ fls2_SAIL

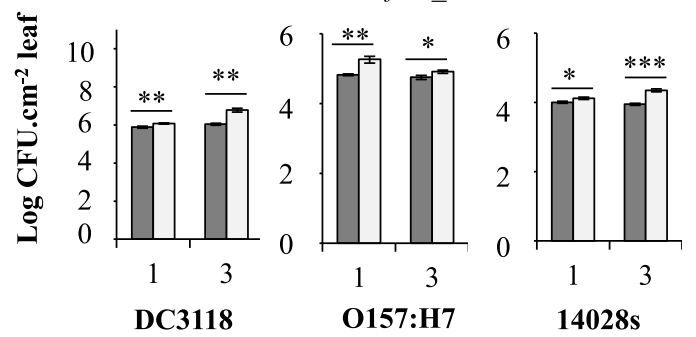

Fig. 4 A functional SA signaling pathway is required to promote bacterial-triggered stomatal closure and apoplastic immunity. Arabidopsis mutants sid2-2, npr1-1 and fls2_SAIL have impaired stomatal and apoplastic defenses against Pst DC3118, E. coli O15:H17, and STm 14,028 s. a Stomatal aperture width was measured $2 \mathrm{~h}$ post inoculation with each bacterium at a concentration $1 \times 10^{8} \mathrm{CFU} \cdot \mathrm{mL}^{-1}$. Results are shown as the average of two independent biological replicates $(n=120 \pm$ SE). b Bacterial population sizes evaluated one and three days after inoculation. Plants were vacuum-inoculated with each bacterium at a concentration of $1 \times 10^{6} \mathrm{CFU} \cdot \mathrm{mL}^{-1}$. Results are shown as the average of two independent biological replicates $(n=12 \pm S E$ ). Note that very small error bars are observed for bacterial growth of mainly human pathogen due to the high reproducibility of the assay. Statistical significance between means (mutant versus Col-0) was detected with two-tailed Student's $t$-test $\left(^{*}=p<\right.$ $0.05 ;{ }^{* *}=p<0.01 ;{ }^{* * *}=p<0.001 ; \mathrm{ns}=$ non-significant). CFU = colony forming unit

when compared with stomata of Col-0 leaves (Fig. 4a), indicating that SA synthesis and signaling also control stomatal aperture in the absence of biotic stress (i.e., bacterium inoculation). All three bacteria maintained a larger apoplastic population in the npr1-1 and sid2-2 mutants than in Col-0, where the population of the phytopathogen Pst DC3118 increased and the population of E. coli O157:H7 and STm 14,028 s persisted at a higher level in these mutant than in the wild type plants throughout the experimentation time (Fig. 4b). These results indicate that SA biosynthesis and signaling through proteins ICS1 and NPR1, respectively, are not only contributes to Arabidopsis defenses against Pst as previously described [42, 51, 53], but also to leaf stomatal and apoplastic defenses against the bacterial human pathogens E. coli $\mathrm{O} 157: \mathrm{H} 7$ and STm 14,028 s.

SA-mediated immunity can be triggered upon detection of MAMPs by transmembrane receptors in the guard cells, such as the FLS2 (FLAGELLIN SENSING 2) that perceive flagellin from bacteria [36, 42, 54, 55]. Therefore, we tested whether flagellin perception through FLS2 plays a role in Arabidopsis defense against STm 14,028 s and E. coli O157:H7 as well. As previously shown $[42,55]$, the fls2_SAIL mutant (Additional file 6) [56]; has impaired stomatal closure in response to Pst DC3118 (Fig. 4a). Interestingly, E. coli O157:H7 triggered enhanced stomatal immunity in fls2_SAIL, while STm $14,028 \mathrm{~s}$ failed to induce stomatal closure in $f l s 2$ SAIL mutant to the same extent as in Col-0 (Fig. 4a). These findings indicate that FLS2 is sufficient for Arabidopsis to recognize Pst DC3118 and STm 14,028 s and activate stomatal closure; however, other MAMPs may redundantly contribute to E. coli O157:H7-triggered stomatal closure. Interestingly, Pst DC3118, but not STm 14,028 s and E. coli O157:H7, failed to induce stomatal closure in fls2-SAIL (Additional file 7). Furthermore, 
apoplastic defense in the fls2_SAIL mutant was compromised in response to all three bacteria, as higher bacterial population was observed inside of this mutant leaf when compared to Col-0 (Fig. 4b). This finding indicates that the FLS2 receptor has a significant role in the perception of Pst, STm 14,028 s, and E. coli $\mathrm{O} 157: \mathrm{H} 7$ by the mesophyll cells, at least in the first three days of interaction.

Altogether, these results suggest that SA signaling components ICS1 and NPR1, as well as the MAMP receptor FLS2, function in plant defense against human pathogens in a similar manner to that of against phytopathogen Pst.

\section{ICS1 and NPR1 contribute to enterobacterium-induced callose production}

Bacterial infection is known to induce cell wall thickening through callose deposition in Arabidopsis [57], a process that is associated with SA signaling [58]. We verified that Pst DC3118, E. coli O157:H7, and STm 14,028 s induce callose deposition in the wild type plant Col-0 (Fig. 3a). Additionally, sid2-2 and npr1-1 mutants showed enhanced susceptibility to STm 14,028 s and E. coli O157:H7 (Fig. 4b). Thus, we tested whether ICS1 and NPR1 are also relevant to callose deposition triggered by these human pathogens by evaluating the area of callose deposits produced in the respective mutant leaves. A significant decreased in callose deposition was observed in both mutants, sid2-2 and npr $1-1$, in response to all bacteria (Fig. 5) suggesting that SA biosynthesis via ICS1 and signaling by NPR1 via callose production is a shared mechanism of Arabidopsis defense against enterobacteria and the phytopathogen Pst.

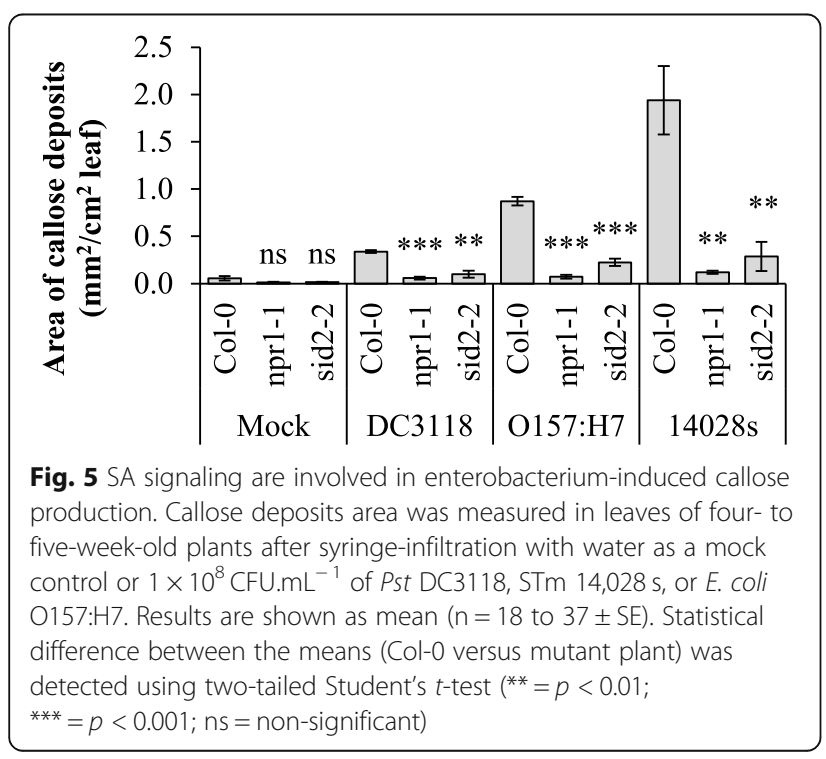

\section{Discussion}

It is well-known that plants can defend themselves against a wide range of microbes through the activation of innate immune responses. Plant defense against plant pathogens has been reported extensively and robust markers for this defense are widely accepted to track these responses. For instance, perception of MAMPs and DAMPs by host transmembrane receptors, ROS production, callose deposition, and hormonal crosstalk are few of widely studied and important defense mechanisms used by plants reviewed by [59]. Although plants are able to respond to human pathogenic bacterial colonization, the molecular mechanisms underlying plant interaction with enterobacteria is a major unexplored area of research. Our study contributes to this field by assessing novel molecular components of plant resistance and determining whether these molecules are associated with hallmark plant defense mechanisms thereby reducing persistence of STm and E. coli O157: H7 in Arabidopsis leaves.

Stomatal defense is an important part of plant innate immunity against plant pathogen attack because it reduces bacterial entry in the leaf apoplast. Stomatal movement is known to require a dynamic guard cell wall, in which synthesis of callose in the guard cells was shown to modulate stomatal movement in the fern Asplenium nidus [60]. Thus, guard cell wall reinforcement mediated by EXO70H4 may be a dynamic process that is activated under plant interaction with enterobacteria, as exo70h4-3 guard cells were impaired in stomatal closure only after inoculation with the human pathogens STm 14,028 s and E. coli O157:H7 (Fig. 2). Additionally, EXO70H4 is part of an exocyst complex at the cell plasma membrane, which contains proteins that are conserved among all eukaryotes [61-63], suggesting strengthening of the cell barriers is a common defense mechanism activated by STm and enterohemorrhagic E. coli in plants and animals. Therefore, it is possible that guard cells differently respond to human and plant pathogens, in which callose deposition is a plant defense mechanism that may have greater importance in the stomatal defense triggered by human pathogens than by Pst DC3118. Further investigation of the molecular components involved in this specific guard cell response to bacteria would contribute to the development of new strategies to diminish fresh produce contamination by STm and E. coli.

Interestingly, E. coli O157:H7 induces a stronger stomatal defense in the fls2_SAIL mutant in comparison to Col-0 (Fig. 4). These corroborate with the notion that other MAMPs (e.g., lipopolysaccharide that is also involved in stomatal immunity [42];), may have a more prominent role in plant perception of E. coli $\mathrm{O} 157: \mathrm{H} 7$ than its flagellin. Downstream of MAMP perception however, an intact SA 
responsive pathway is required for stomatal defense against E. coli $\mathrm{O} 157: \mathrm{H} 7$, as well as against STm $14,028 \mathrm{~s}$ and Pst DC3118 (Fig. 4). This result indicates that SA biosynthesis by ICS1 and signaling through NPR1 are a common mechanism for stomatal defense against phytopathogens [55] and enterobacteria (Fig. 4).

Previous studies have identified a large set of Arabidopsis genes regulated by E. coli $\mathrm{O} 157: \mathrm{H} 7$ in a flagellindependent manner $[43,45]$, indicating that this human pathogen activates basal defense mechanisms in the plant apoplast. Likewise, we found that STm SL1344 modulates plant immune responses in Arabidopsis adult leaves (Fig. 1), similar to STm 14,028 s in Arabidopsis seedlings [32, 38]. Among the activated processes, genes involved in ROS burst and cell wall modifications were overrepresented by genes induced after STm SL1344 inoculation, suggesting that these processes play a role in plant basal defense against this human pathogen. A common cell wall modification induced by microbes in plants is the deposition of callose in the infected area reviewed by [49]; a process induced by both SA and flagellin to suppress bacterial growth $[64,65]$.

Interestingly, flagellin induces the expression of EXO7OH4, NPR1 and ICS1 [66]. Furthermore, EXO70H4 is essential for the secretion of the stress-inducible callose synthase CalS12, also known as POWDERY MILDEW RESISTANT4 (PMR4), which contributes to cell wall strengthening of leaf trichomes [48, 66]. Expression of PMR4 is strongly induced by SA in a NPR1dependent manner [58]. These findings indicate that EXO7H4 could function dependently of NPR1. Indeed, we observed that EXO70H4, together with NPR1 and ICS1, were all involved in callose deposition in response to STm 14,028 s, E. coli O157:H7, and Pst DC3118 (Fig. 3 and Fig. 5). Additionally, decreased callose deposition in the exo70h4-3 mutant was associated with its compromised apoplastic immunity against STm 14,028 s and Pst DC3118 (Fig. 2). We have not observed increased $E$. coli $\mathrm{O} 157: \mathrm{H} 7$ titer in the exo70h4-3 mutant. However, it is possible that either EXO70H4 has no function in apoplastic immunity against E. coli $\mathrm{O} 157: \mathrm{H} 7$ or this bacterium induces redundant apoplastic immune responses in Arabidopsis leaves. Nonetheless, these results support the role of EXO70H4, NPR1, and ICS1 in the control of persistence of human pathogens in leaves at the preand/or post-invasion stage of infection (Figs. 2 and 4), and suggest that the plant defense mediated by these proteins involves callose production.

\section{Conclusion}

Stomatal defense against STm and E. coli O157:H7 have common mechanisms, requiring $\mathrm{EXO} 70 \mathrm{H} 4$, the SA signaling components NPR1 and ICS1, as well as the MAMP receptor FLS2, differently from stomatal defense against
Pst DC3118 that does not involve EXO70H4. By contrast, STm 14,028 s and Pst DC3118 induce similar responses in the leaf mesophyll, as EXO70H4, NPR1, ICS1, and FLS2 are involved in decreasing bacterial populations inside Arabidopsis leaves. Moreover, EXO70H4, NPR1, and ICS1 mediated basal defense via callose deposition is a common plant response against both human and plant pathogens. Although, EXO70H4 is not sufficient to inhibit E. coli O157:H7 colonization of the leaf apoplast.

This study provides new insights into genetic mechanism of plant defense against two enterobacteria relevant to public health. Understanding the mechanisms underlying bacterium persistence in edible leaves may facilitate implementation of preventive measures to control foodborne diseases and ultimately improve the quality, safety, and marketability of fresh produce.

\section{Methods}

\section{Plant material and growth conditions}

The seeds of Arabidopsis thaliana (L. Heyhn.) wild type ecotype Columbia (Col-0, ABRC stock CS60000) and the 4 derived mutants (Additional file 6; Additional file 8) were sown in a 1:1:1 v:v:v mixture of growing medium (Redi-earth plug and seedling mix, Sun Gro), fine vermiculite, and perlite and grown in controlled environmental chambers at $22 \pm 2{ }^{\circ} \mathrm{C}, \quad 60 \pm 10 \%$ relative humidity, and a 12-h photoperiod under light intensity of $100 \mu \mathrm{mol} \cdot \mathrm{m}^{-2} \cdot \mathrm{s}^{-1}$. For all experiments, four- to fiveweek old plants were used.

\section{Bacterial strains and culturing conditions}

Pseudomonas syringae pv. tomato (Pst) strain DC3118 (a coronatine-deficient mutant of the Pst DC3000 wild type [67];), Escherichia coli serotype O157:H7 strain 86-24 [68] and Salmonella enterica subsp. enterica serovar Typhimurium strains SL1344 and 14,028 s [69] were used in this study. Bacterial cultures were grown in Low Salt Luria-Bertani medium (LSLB; $10 \mathrm{~g} / \mathrm{L}$ tryptone, $5 \mathrm{~g} / \mathrm{L}$ yeast extract, $5 \mathrm{~g} / \mathrm{L} \mathrm{NaCl}, \mathrm{pH}=7.0$ ) at $28^{\circ} \mathrm{C}$ for all experiments. Cells were freshly streaked on solid medium from frozen glycerol stocks prior to inoculum preparation. The culture medium was supplemented with streptomycin $(50 \mu \mathrm{g} / \mathrm{mL})$ to grow E. coli $\mathrm{O} 157: \mathrm{H} 7$, spectinomycin $(100 \mu \mathrm{g} / \mathrm{ml})$ to grow STm SL1344, or rifampin $(100 \mu \mathrm{g} / \mathrm{mL})$ and kanamycin $(50 \mu \mathrm{g} / \mathrm{mL})$ to grow Pst DC3118. STm 14,028 s has no resistance to antibiotics.

\section{Array hybridization assay}

A total of 30 Arabidopsis Col-0 plants were grown as described above. STm SL1344 was cultured in liquid LSLB medium and incubated overnight in an orbital shaker at $30^{\circ} \mathrm{C}$. Inoculum was prepared by harvesting bacterial cells when the culture reached $\mathrm{OD}_{600}$ of $0.8-0.9$. The inoculum with a final concentration of $1 \times 10^{8} \mathrm{CFU} \cdot \mathrm{mL}^{-1}$, 
supplemented with $0.004 \%$ Silwet, was vacuuminfiltrated into the leaf intercellular space of 15 plants as previously described [70]. As mock control, 15 plants were vacuum-infiltrated with water with $0.004 \%$ Silwet L-77. After inoculation, plants were kept at $25^{\circ} \mathrm{C}$ for $7 \mathrm{~h}$ until leaves were collected for RNA extraction using $\mathrm{TRizol}^{\circ}$ reagent (Life Technologies, Grand Island, NY) according to manufacturer's instruction. Total RNA was quantified through NanoDrop 2000c spectrophotometer (Thermo Scientific, Rockford, IL). RNA quality was assessed by using the Agilent 2010 Bioanalyzer.

Arabidopsis Affymetrix GeneChip ATH1 (Thermo Scientific, Rockford, IL) array hybridizations were conducted in three biological replicates (i.e., independent repetitions of the whole experiment, composed of 5 plants per treatment) at Michigan State University Research Technology Support Facility exactly as described by 43. Raw data of the biological replicates is available in a MIAME-compliant format at the Nottingham Arabidopsis Stock Centre (NASC; http://nasc.cott.ac.uk/) under the Experiment ID NASCARRAYS-674.

\section{Differential gene expression analysis}

Gene expression data were normalized using Robust Multichip Averaging (RMA) normalization across all biological replicates, using the "affylmgui" package (version 1.10.4), available as part of the Bioconductor software package for R [71]. Pairwise $\log _{2}$ fold change values (average of the three biological replicates) were calculated between mock- and STm SL1344-inoculated leaves based on the RMA-normalized relative expression values using Microsoft Excel software (Version 2010). Additionally, a Z-ratio-based approach was used to identify differentially expressed genes according to the methods outlined in 46 . The Z-ratio approach determines which genes have significantly higher fold changes than other genes in the dataset. A Z-ratio cutoff of 2.33 (Additional file 1) was used to call approximately $2 \%$ of the genes in each dataset as being differentially expressed.

Differentially expressed genes were categorized based in their Gene Ontology (GO) annotations using the Singular Enrichment Anlysis (SEA) tool from agriGO v2.0 (http://systemsbiology.cau.edu.cn/agriGOv2/index.php; [72]). GO enrichment was obtained by using the reference dataset gene model TAIR10 (28,362 genome locus) and the complete GO gene ontology type. Statistical significance was detected with the Fisher's exact test followed by the Yekutieli-False Discovery Rate multiple test correction $(\mathrm{FDR}<0.05)$.

\section{Microarray data validation by RT-qPCR}

Total RNA was extracted from leaves using RNeasy Plant Mini Kit (Qiagen Inc., Valencia, CA) and quantified using a NanoDrop spectrophotometer (Thermo
Scientific, Rockford, IL). Total RNA (1 $\mu \mathrm{g})$ was synthesized into cDNA using the Takara RNA PCR kit (AMV) (Clontech, Montain View, CA) and diluted to a final concentration of $50 \mathrm{ng} . \mu \mathrm{L}^{-1}$. The Reverse Transcription Quantitative PCR (RT-qPCR) reaction $(20 \mu \mathrm{L})$ was performed with $10 \mu \mathrm{L}$ of iTaq Fast SYBR Green Supermix (BioRad, Hercules, CA), $2 \mu \mathrm{L}$ of cDNA template from the reverse transcriptase reaction described above, and $200 \mathrm{nM}$ of reverse and forward gene-specific primers. Reactions were carried out in an Applied Biosystems 7300 thermocycler (Applied Biosystems, Foster City, CA) using the following cycling parameter: 1 cycle $95^{\circ} \mathrm{C}$ for 5 min and 40 cycles of $95^{\circ} \mathrm{C}$ for $10 \mathrm{~s}$ and $60^{\circ} \mathrm{C}$ for 30 $\mathrm{s}$. A dissociation curve was determined for every reaction to confirm the presence of a single amplicon indicating the lack of primer dimers and non-specific products, and that RNA samples were free of DNA contamination. Gene expression levels relative to the mock-inoculated control were calculated using the $\Delta \Delta \mathrm{Ct}$ method [73] considering the expression of the housekeeping gene ACT8 as the internal control and the expression value of the mock-treated samples was set as 1 . Two biological replicates (each composed of a bulk of three leaves of one plant) and three technical replicates were performed and statistical significance between the means was calculated with Student's $t$-test.

Gene-specific primer sets that span an intron region were designed using the primer quest software from IDT-SciTools (http://www.idtdna.com/Primerquest/Home/ Index). Efficiencies of each pair of primer were evaluated by calculating the linear regression between the five-fold serial dilution of a cDNA pool and the cycle threshold (CT) values. Only primer sets with a correlation coefficient $\left(R^{2}\right)>$ 0.97 were used. Gene-specific primer sequences are described in the Additional file 9. Two biological replicates and three technical replicates were performed.

\section{Genotyping of Arabidopsis mutants}

To determine the T-DNA insertion or point mutation for each Arabidopsis mutant (Additional file 8), around $5 \mathrm{mg}$ of fresh leaf tissue of one plant of each genotype was grounded in $200 \mu \mathrm{L}$ of Edwards Solution [74] for DNA extraction. PCR reaction $(25 \mu \mathrm{L})$ was performed with $1 \mathrm{U}$ DNA polymerase Gotaq (Promega, WI, USA), 1x enzyme buffer, $1.5 \mathrm{mM} \mathrm{MgCl}_{2}, 200 \mu \mathrm{M}$ dNTP, $1 \mu \mathrm{L}$ of gDNA template, and $400 \mathrm{nM}$ of reverse and forward specific primers (Additional file 8). Reactions were carried out using the following cycling parameter: 1 cycle $95^{\circ} \mathrm{C}$ for $5 \mathrm{~min}$ and 40 cycles of $95^{\circ} \mathrm{C}$ for $30 \mathrm{~s}, 52^{\circ} \mathrm{C}$ for $30 \mathrm{~s}$ and $72{ }^{\circ} \mathrm{C}$ for 1 min, with final extension of $72^{\circ} \mathrm{C}$ for $10 \mathrm{~min}$. Mutants sid2-2 and npr1-1 were previously obtained using fast neutrons and ethylmethane sulfonate methods, respectively. Thus, the rearrangement and point mutation in these plants were verified by either presence or absence of 
the amplicon for sid2-2 [51] or by an additional step of restriction enzyme digestion with the enzyme NlaIII (New England Biolabs, Ipswich, MA) after PCR amplification for npr1-1 [52]. Amplicons were visualized after gel electrophoresis using the UV light on a C300 imaging system (Azure Biosystems, CA, USA).

\section{Stomatal bioassay}

To examine the stomatal immunity of mutant plants against Pst DC3118, E. coli O157:H7, and STm 14,028 s, stomatal bioassays were conducted as previously described [75]. Briefly, three leaves of four- to five-week old plants were floated in water (mock control) or in $1 \times 10^{8} \mathrm{CFU} \cdot \mathrm{mL}^{-1}$ of Pst DC3118, E. coli O157:H7, or STm $14,028 \mathrm{~s}$. Experiments initiated $3 \mathrm{~h}$ after dawn to ensure that stomata were open. Floating leaves were kept at $25^{\circ} \mathrm{C}$ and light intensity of $100 \mu \mathrm{mol} . \mathrm{m}^{-2} . \mathrm{s}^{-1}$ for the duration of the experiment. Stomatal images and aperture width measurements were obtained with a Nikon Eclipse 80i fluorescent microscope (Nikon Corporations, Shinagawa-ku, Tokyo, Japan), equipped with longdistance objectives. Data points represent the mean of two independent biological replicates, which were composed of 60 stomata of three leaves of one plant per treatment $(n=120) \pm$ standard error (SE). Statistical analyses of each bacterium (or water) treatment, in each mutant in relation to the wild type Col-0 were performed using the Student's $t$-test.

\section{Bacterial pathogenesis assays}

Bacterial strains were cultured at $28^{\circ} \mathrm{C}$ in LSLB medium supplemented with appropriate antibiotics until an $\mathrm{OD}_{600}$ of 0.8 to 1.0 was reached. To prepare the inoculum, bacteria were collected by centrifugation and suspended in water to a final concentration of $1 \times 10^{6} \mathrm{CFU} \cdot \mathrm{mL}^{-1}$ and supplemented with $0.008 \%$ Silwet L-77 (Lehle Seeds Co., Round Rock, TX). Plants were vacuum-infiltrated with the same inoculum to ensure uniform inoculation across the plant genotypes tested. Inoculated plants were immediately incubated under the following conditions: $25^{\circ} \mathrm{C}$, $80 \pm 10 \%$ relative humidity, $12 \mathrm{~h}$ of photoperiod $\left(100 \mu \mathrm{mol} . \mathrm{m}^{-2} \cdot \mathrm{sec}^{-1}\right)$ for the duration of the experiment. Bacterial population in the plant apoplast was determined as previously described [70, 76]. Data points represent the mean $(n=12) \pm S E$ of three leaves (each with two technical replicates) of one plant per data point in two independent experiments. Statistical analyses were performed by comparing the bacterium titer in each mutant with that of the wild type Col-0 using the Student's $t$-test.

\section{Callose deposition measurements}

Callose staining was performed as described previously [77]. Briefly, fully expanded leaves of four- to five-weekold plants were syringe-infiltrated with $1 \times 10^{8} \mathrm{CFU} \cdot \mathrm{mL}^{-1}$ of Pst DC3118, STm 14,028 s, E. coli O157:H7, or water (mock control). Infiltrated leaves were harvested $7 \mathrm{hpi}$, cleared with 95\% ethanol overnight, rehydrated with 50\% ethanol and $150 \mathrm{mM} \mathrm{K}_{2} \mathrm{HPO}_{4}$, and stained with $0.01 \%$ Aniline Blue dissolved in $150 \mathrm{mM} \mathrm{K} \mathrm{HPO}_{4}$. Stained material was mounted in $40 \%$ glycerol and examined using a Nikon Eclipse 80i fluorescent microscope (Nikon Corporations, Shinagawa-ku, Tokyo, Japan), equipped with a DAPI filter (358-nm excitation and 461-nm emission) and a digital camera. Callose deposition area $\left(\mathrm{mm}^{2} / \mathrm{cm}^{2}\right.$ of leaf) was quantified by analyzing the digital images using the Binary Area measurement tool and ROI statistics of the software Nikon NIS-Elements AR version 4.13. Data points are representative of two experiments performed independently with similar results. Each experiment was conducted with three to four biological replicates each (one plant per biological replicate per treatment), and an average of 8 to 10 pictures per biological replicate $(n=18$ to 37$) \pm$ SE. Statistical analysis was performed using the Student's $t$-test to compare the mean callose area in each mutant plant with the wild type plant Col-0.

\section{ROS production measurements}

ROS detection was monitored by a luminol-based assay [78]. Young, fully expanded leaves of four- to five-weekold plants were used for this assay. A minimum of 8 leaf discs ( $4 \mathrm{~mm}$ in diameter) of three plants per genotype/ treatment were cut with a cork borer and individually incubated overnight in $150 \mu \mathrm{L}$ of sterile water on an opaque white 96-well plates (Thermo Scientific, Rockford, IL). In the next day, the water was replaced with a solution containing $34 \mu \mathrm{g} / \mathrm{mL}$ luminol (Sigma-Aldrich, St. Louis, MO, USA), $20 \mu \mathrm{g} / \mathrm{mL}$ horseradish peroxidase type VI (HRP, Sigma-Aldrich, St. Louis, MO, USA) and $1 \times 10^{8}$ CFU.mL ${ }^{-1}$ of boiled Pst DC3118, STm 14,028 s, or E. coli O157:H7, or water as a mock control. Luminescence was recorded over $60 \mathrm{~min}$ using a Synergy $\mathrm{y}^{\mathrm{nm}} \mathrm{H} 1$ microplate reader (Biotek, Winooski, VT, USA) and analyzed using the plate reader software Biotek Gen5 (Biotek, Winooski, VT, USA). Data points are the mean of three independent biological replicates $(n=21$ to 37$) \pm$ SE.

\section{Supplementary information}

Supplementary information accompanies this paper at https://doi.org/10. 1186/s12870-019-2232-x.

Additional file 1. Z-ratio analysis of the microarray dataset. (a) Normalized Z-ratio of array intensity data shows a normal distribution of all genes expressed in the STm SL1344-treated leaves as compared to the mock control. The $2 \%$ extremes of the bell-shape curve reveal the genes with significant differential expression. (b) Linear regression between relative gene expression calculated with two methods, Z-ratio and $\log _{2}$ fold change, shows high positive correlation $\left(R^{2}=0.9676\right)$.

Additional file 2. Relative gene expression analysis (mock- versus SL1344-treated leaves) using Log2 Fold Change and Z-ratio methods. Gene expression for each gene was calculated based on an average of 
three biological replicates. A total of 541 array probes corresponding to 585 genes were identified as differentially expessed based on Z-ratio analysis (the extreme $2 \%$ of up or down-regulated). Genes hilightes in bold had their expression evaluated by RT-qPCR.

Additional file 3. Validation of microarray analysis by RT-qPCR. Arabidopsis leaves were infiltrated with STm SL1344 $\left(1 \times 10^{8} \mathrm{CFU} \cdot \mathrm{mL}^{-1}\right)$ or water as a mock control. Expression of randomly selected genes was normalized to the expression of the housekeeping gene ACT8 (AT1G49240) Gene expression levels in the STm 1344-treated samples relative to the mock-treated samples (value set as 1) were calculated using the $\Delta \Delta C t$ method [73]. Results are shown as average $(n=6 \pm$ SE) and statistical difference between the means (STm SL1344 vs. mock) was determined using Student's t-test $\left(^{*}=p<0.05,{ }^{* *}=p<0.01,{ }^{* * *}=p<0.001\right.$, ns $=$ nonsignificant).

Additional file 4. GO Single Enrichment Analysis (SEA) of genes upregulated (310 genes) or down-regulated (275 genes) by SL1344, using the online tool AgriGO. Only GO terms that contained more than 5 entries and were significantly over-represented $(F D R<0.05)$ in the query dataset are shown. Query items indicate the number of SL1344-regulated genes in each $\mathrm{GO}$ term, and background items indicate the number of annotated genes in the Arabidopsis genome (TAIR10) for each GO term. Statistical significance was calculated with Fisher's exact test and Yekutieli-False Discovery Rate (FDR) multiple test correction. The ontology terms used are Biological Process (P), Molecular Function (F), and Cellular Component (C). Terms in bold are present in both up- and downregulated datasets.

Additional file 5. Hierarchical organization of all $11 \mathrm{GO}$ terms enriched in both STm up- and down-regulated gene datasets.

Additional file 6. Arabidopsis mutant genotyping. (a) Genomic DNA for each T-DNA insertion mutant plant (fls__SAlL or exo70h4-3) and the wild type Col-0 was used as a template in PCR amplification with genespecific primers listed in the Additional file 8 . Reactions loaded onto lane 1 contained the LP (left primer) and RP (right primer) set to amplify the wild type allele in Col-0, whereas reactions loaded onto lane 2 contained a T-DNA specific primer and the RP primer to amplify the mutant allele. (b) The sid2-2 mutant was created with fast neutron [51] and the point mutation was verified by the absence of amplification using gene-specific primers. Amplification of the ACT2 gene was used as a positive control for the PCR amplification. (c) The npr1-1 mutant was created with ethylmethane sulfonate [52] and the point mutation was verified by digesting the PCR amplicon with the restriction enzyme Nlalll.

Additional file 7. Statistical analyses for bacterial mediated-stomatal closure shown in Fig. 2a and Fig. 4a. Statistical analyses were performed by comparing water- with bacterium-treated plants using the Student's ttest. All comparisons showed statistical significance evidenced by the low $p$-value, except for the fls2-SAlL mutant when comparing water with Pst DC3118 treatment.

Additional file 8. List of Arabidopsis mutants and primer sequences used to validate the mutation.

Additional file 9. Sequence of primers used to validate the microarray results by RT-qPCR analysis.

\section{Abbreviations}

ACT2: ACTIN 2; CDNA: Complementary DNA; CT: Cycle Threshold; DAl: Day(s) After Inoculation; DNA: Deoxyribonucleic Acid; dNTP: Deoxynucleotide Triphosphate; EXO70H4: EXOCYST SUBUNIT EXO70 FAMILY PROTEIN H4; FDOSS: Foodborne Disease Outbreak Surveillance System; FDR: False Discovery Rate; Flg15 e. coli: 15 amino acid-peptide derived from the Escherichia coli flagellin; FLS2: FLAGELLIN SENSING 2; FSMA: Food Safety Modernization Act; gDNA: Genomic DNA; GO: Gene Ontology; hpi: Hours Post Inoculation; ICS1: ISOCHORISMATE SYNTHASE 1; LSLB: Low Salt LuriaBertani; MAMP: Microbe-Associated Molecular Patterns; MTI: MAMP-Triggered Immunity; NPR1: NON-EXPRESSER OF PATHOGENESIS-RELATED GENE 1; OD: Optical Density; PCR: Polymerase Chain Reaction; Pst: Pseudomonas syringae pv. tomato; $\mathrm{R}^{2}$ : Correlation Coefficient; RMA: Robust Multichip Averaging; RNA: Ribonucleic Acid; ROS: Reactive Oxygen Species; RTqPCR: Reverse Transcriptase-quantitative PCR; SA: Salicylic Acid; SE: Standard Error; SEA: Single Enrichment Analysis; Seflg22: 22 amino acid-peptide derived from the Salmonella enterica flagellin; STm: S. enterica serovar Typhimurium; TAIR: The Arabidopsis Information Resource; UV: Ultraviolet

\section{Acknowledgments}

We would like to thank Shweta Panchal, Bruce Rosa, Giselle de Carvalho, and Mariana Vaz Bisneta for technical assistance with plant RNA extraction, Zratio analysis, RT-qPCR experiments, and plant mutant genotyping, respectively.

\section{Authors' contributions}

MM conceived the research; PRO and MM designed the research and supervised the experiments; PRO and CCM performed research; MM contributed material/analytic tools; PRO, CCM, and MM analyzed the data; PRO and MM wrote the article. All authors have read and approved the manuscript.

\section{Funding}

This work was supported in part by a grant from the U.S. National Institute of Allergy and Infectious Disease (5R01Al068718), the U.S. Department of Agriculture - National Institute of Food and Agriculture (NIFA; 2015-6701723360 and 2017-67017-26180), and NIFA Hatch (CA-D-PLS-2327-H) to M.M. Funding bodies had no role in the design of the study and collection, analysis, and interpretation of data and in writing the manuscript.

\section{Availability of data and materials}

Microarray data is available in the MIAME-compliant format at the Nottingham Arabidopsis Stock Centre. Raw data can be downloaded from http:// bar.utoronto.ca/NASCArrays/index.php?ExpID=674 under the Experiment ID NASCARRAYS-674

\section{Ethics approval and consent to participate}

Not applicable.

\section{Consent for publication}

Not applicable.

\section{Competing interests}

The authors declare that they have no competing interests.

Received: 10 May 2019 Accepted: 30 December 2019

Published online: 08 January 2020

\section{References}

1. World Health Organization. WHO estimates of the global burden of foodborne diseases: foodborne diseases burden epidemiology reference group 2007-2015. Geneva: WHO Press, World Health Organization; 2015. p 256.

2. Bennett SD, Sodha SV, Ayers TL, Lynch MF, Gould LH, Tauxe RV. Produceassociated foodborne disease outbreaks, USA, 1998-2013. Epidemiol Infect. 2018:146:1-10.

3. Takeuchi K, Hassan AN, Frank JF. Penetration of Escherichia coli O157:H7 into lettuce as influenced by modified atmosphere and temperature. J Food Prot. 2001;64(11):1820-3.

4. Dong Y, Iniguez AL, Ahmer BM, Triplett EW. Kinetics and strain specificity of rhizosphere and endophytic colonization by enteric bacteria on seedlings of Medicago sativa and Medicago truncatula. Appl Environ Microbiol. 2003; 69(3):1783-90

5. Barak JD, Gorski L, Naraghi-Arani P, Charkowski AO. Salmonella enterica virulence genes are required for bacterial attachment to plant tissue. Appl Environ Microbiol. 2005;71(10):5685-91.

6. Barak JD, Kramer LC, Hao LY. Colonization of tomato plants by Salmonella enterica is cultivar dependent, and type 1 trichomes are preferred colonization sites. Appl Environ Microbiol. 2011;77(2):498-504

7. Iniguez AL, Dong Y, Carter HD, Ahmer BM, Stone JM, Triplett EW. Regulation of enteric endophytic bacterial colonization by plant defenses. Mol Plant Microbe Interact. 2005;18(2):169-78.

8. Schikora A Carreri A, Charpentier E, Hirt H. The dark side of the salad: Salmonella typhimurium overcomes the innate immune response of Arabidopsis thaliana and shows an endopathogenic lifestyle. PLoS One. 2008;3(5):e2279. 
9. Saggers EJ, Waspe CR, Parker ML, Waldron KW, Brocklehurst TF. Salmonella must be viable in order to attach to the surface of prepared vegetable tissues. J Appl Microbiol. 2008;105(5):1239-45.

10. Kroupitski Y, Golberg D, Belausov E, Pinto R, Swartzberg D, Granot D, Sela S. Internalization of Salmonella enterica in leaves is induced by light and involves chemotaxis and penetration through open stomata. Appl Environ Microbiol. 2009;75(19):6076-86

11. Kroupitski Y, Pinto R, Brandl MT, Belausov E, Sela S. Interactions of Salmonella enterica with lettuce leaves. J Appl Microbiol. 2009;106(6):1876-85.

12. Berger CN, Shaw RK, Brown DJ, Mather H, Clare S, Dougan G, et al. Interaction of Salmonella enterica with basil and other salad leaves. ISME J. 2009;3(2):261-5.

13. Berger CN, Shaw RK, Ruiz-Perez F, Nataro JP, Henderson IR, Pallen MJ, Frankel G. Interaction of enteroaggregative Escherichia coli with salad leaves. Environ Microbiol Rep. 2009;1(4):234-9.

14. Golberg D, Kroupitski Y, Belausov E, Pinto R, Sela S. Salmonella Typhimurium internalization is variable in leafy vegetables and fresh herbs. Int J Food Microbiol. 2011;145(1):250-7.

15. Seo S, Matthews KR. Influence of the plant defense response to Escherichid coli 0157: H7 cell surface structures on survival of that enteric pathogen on plant surfaces. Appl Environ Microbiol. 2012;78(16):5882-9.

16. Méric G, Kemsley EK, Falush D, Saggers EJ, Lucchini S. Phylogenetic distribution of traits associated with plant colonization in Escherichia coli. Environ Microbiol. 2013;15(2):487-501.

17. Roy D, Panchal S, Rosa BA, Melotto M. Escherichia coli O157: H7 induces stronger plant immunity than Salmonella enterica Typhimurium SL1344. Phytopathol. 2013;103(4):326-32.

18. Rossez Y, Holmes A, Wolfson EB, Gally DL, Mahajan A, Pedersen HL, Holden NJ. Flagella interact with ionic plant lipids to mediate adherence of pathogenic Escherichia coli to fresh produce plants. Environ Microbiol. 2014; 16(7):2181-95

19. Aguilera-Herce J, Zarkani AA, Schikora A, Ramos-Morales F. Dual expression of the Salmonella effector SrfJ in mammalian cells and plants. Front Microbiol. 2017:8:2410-26.

20. Chalupowicz L, Nissan G, Brandl MT, McClelland M, Sessa G, Popov G, et al. Assessing the ability of Salmonella enterica to translocate type III effectors into plant cells. Mol Plant Microbe Interact. 2018;31(2):233-9.

21. Jang H, Matthews KR. Influence of surface polysaccharides of Escherichia coli 0157:H7 on plant defense response and survival of the human enteric pathogen on Arabidopsis thaliana and lettuce (Lactuca sativa). Food Microbiol. 2018;70:254-61.

22. Roy D, Melotto M. Stomatal response and human pathogen persistence in leafy greens under preharvest and postharvest environmental conditions. Postharvest Biol Technol. 2019;148:76-82.

23. Wahlig TA, Bixler BJ, Valdés-López O, Mysore KS, Wen J, Ané JM, Kaspar CW. Salmonella enterica serovar Typhimurium ATCC 14028 S is tolerant to plant defenses triggered by the flagellin receptor FLS2. FEMS Microbiol Lett. 2019; 366(4):fny296.

24. Brandl MT, Mandrell RE. Fitness of Salmonella enterica serovar Thompson in the cilantro phyllosphere. Appl Environ Microbiol. 2002;68(7):3614-21.

25. Solomon EB, Yaron S, Matthews KR. Transmission of Escherichia coli O157:H7 from contaminated manure and irrigation water to lettuce plant tissue and its subsequent internalization. Appl Environ Microbiol. 2002;68(1):397-400.

26. Solomon EB, Potenski CJ, Matthews KR. Effect of irrigation method on transmission to and persistence of Escherichia coli 0157:H7 on lettuce. J Food Prot. 2002;65(4):673-6.

27. Cooley MB, Miller WG, Mandrell RE. Colonization of Arabidopsis thaliana with Salmonella enterica and enterohemorrhagic Escherichia coli O157:H7 and competition by Enterobacter asburiae. Appl Environ Microbiol. 2003;69(8): 4915-26.

28. Gu G, Hu J, Cevallos-Cevallos JM, Richardson SM, Bartz JA, Van Bruggen AH. Internal colonization of Salmonella enterica serovar Typhimurium in tomato plants. PLoS One. 2011;6(11):e27340.

29. Wright KM, Crozier L, Marshall J, Merget B, Holmes A, Holden NJ. Differences in internalization and growth of Escherichia coli 0157:H7 within the apoplast of edible plants, spinach and lettuce, compared with the model species Nicotiana benthamiana. J Microbial Biotechnol. 2017;10(3):555-69.

30. Seo KH, Frank JF. Attachment of Escherichia coli 0157: H7 to lettuce leaf surface and bacterial viability in response to chlorine treatment as demonstrated by using confocal scanning laser microscopy. J Food Prot. 1999;62(1):3-9.
31. Saldaña Z, Sánchez E, Xicohtencatl-Cortes J, Puente JL, Girón JA. Surface structures involved in plant stomata and leaf colonization by Shigatoxigenic Escherichia coli O157: H7. Front Microbiol. 2011;2:119.

32. Schikora A, Virlogeux-Payant I, Bueso E, Garcia AV, Nilau T, Charrier A, et al. Conservation of Salmonella infection mechanisms in plants and animals. PLoS One. 2011;6:e24112.

33. Barak JD, Schroeder BK. Interrelationships of food safety and plant pathology: the life cycle of human pathogens on plants. Annu Rev Phytopathol. 2012;50:241-66.

34. Melotto M, Panchal S, Roy D. Plant innate immunity against human bacterial pathogens. Front Microbiol. 2014;5:411.

35. Gómez-Gómez L, Boller T. FLS2: an LRR receptor-like kinase involved in the perception of the bacterial elicitor flagellin in Arabidopsis. Mol Cell. 2000; 5(6):1003-11.

36. Zipfel C, Robatzek S, Navarro L, Oakeley EJ, Jones JD, Felix G, Boller T. Bacterial disease resistance in Arabidopsis through flagellin perception. Nature. 2004;428(6984):764

37. Meng F, Altier C, Martin GB. Salmonella colonization activates the plant immune system and benefits from association with plant pathogenic bacteria. Environ Microbiol. 2013;15(9):2418-30.

38. Garcia AV, Charrier A, Schikora A, Bigeard J, Pateyron S, de Tauzia-Moreau $\mathrm{ML}$, et al. Salmonella enterica flagellin is recognized via FLS2 and activates PAMP-triggered immunity in Arabidopsis thaliana. Mol Plant. 2014;7(4):65774.

39. Meindl T, Boller T, Felix G. The bacterial elicitor flagellin activates its receptor in tomato cells according to the address-message concept. Plant Cell. 2000; 12(9):1783-94.

40. Bauer Z, Gómez-Gómez L, Boller T, Felix G. Sensitivity of different ecotypes and mutants of Arabidopsis thaliana towards the bacterial elicitor flagellin correlates with the presence of receptor binding sites. J Biol Chem. 2001; 276:45669-76.

41. Robatzek S, Bittel P, Chinchilla D, Köchner P, Felix G, Shiu SH, Boller T. Molecular identification and characterization of the tomato flagellin receptor LeFLS2, an orthologue of Arabidopsis FLS2 exhibiting characteristically different perception specificities. Plant Mol Biol. 2007;64(5): 539-47.

42. Melotto M, Underwood W, Koczan J, Nomura K, He SY. Plant stomata function in innate immunity against bacterial invasion. Cell. 2006;126(5):969-80.

43. Thilmony R, Underwood W, He SY. Genome-wide transcriptional analysis of the Arabidopsis thaliana interaction with the plant pathogen Pseudomonas syringae pv. tomato DC3000 and the human pathogen Escherichia coli 0157 H7. Plant J. 2006;46(1):34-53.

44. Jayaraman D, Valdés-López O, Kaspar CW, Ané JM. Response of Medicago truncatula seedlings to colonization by Salmonella enterica and Escherichia coli O157:H7. PLoS One. 2014;9(2):e87970.

45. Golubov A, Byeon B, Woycicki R, Laing C, Gannon V, Kovalchuk I. Transcriptomic profiling of Arabidopsis thaliana plants exposed to the human pathogen Escherichia coli O157-H7. Biocatal Agric Biotechnol. 2016:8:86-96.

46. Cheadle C, Vawter MP, Freed WJ, Becker KG. Analysis of microarray data using Z score transformation. J Mol Diagn. 2003;5(2):73-81.

47. Haslbeck $M$, Vierling $E$. A first line of stress defense: small heat shock proteins and their function in protein homeostasis. J Mol Biol. 2015;427(7): 1537-48.

48. Kulich I, Vojtíková Z, Glanc M, Ortmannová J, Rasmann S, Žárský V. Cell wall maturation of Arabidopsis trichomes is dependent on exocyst subunit EXO70H4 and involves callose deposition. Plant Physiol. 2015;168(1):120-31.

49. Ellinger D, Voigt CA. Callose biosynthesis in Arabidopsis with a focus on pathogen response: what we have learned within the last decade. Ann Bot. 2014;114(6):1349-58

50. Daudi A, Cheng Z, O'Brien JA, et al. The apoplastic oxidative burst peroxidase in Arabidopsis is a major component of pattern-triggered immunity. Plant Cell. 2012;24:275-87.

51. Wildermuth MC, Dewdney J, Wu G, Ausubel FM. Isochorismate synthase is required to synthesize salicylic acid for plant defence. Nature. 2001; 414(6863):562.

52. Li X, Zhang Y, Clarke JD, Li Y, Dong X. Identification and cloning of a negative regulator of systemic acquired resistance, SNI1, through a screen for suppressors of npr1-1. Cell. 1999:98(3):329-39.

53. Ekengren SK, Liu Y, Schiff M, Dinesh-Kumar SP, Martin GB. Two MAPK cascades, NPR1, and TGA transcription factors play a role in Pto-mediated disease resistance in tomato. Plant J. 2003;36(6):905-17. 
54. Tsuda K, Sato M, Glazebrook J, Cohen JD, Katagiri F. Interplay between MAMP-triggered and SA-mediated defense responses. Plant J. 2008;53(5): 763-75

55. Zeng W, He SY. A prominent role of the flagellin receptor FLAGELLINSENSING2 in mediating stomatal response to Pseudomonas syringae pv tomato DC3000 in Arabidopsis. Plant Physiol. 2010;153(3):1188-98.

56. Danna CH, Millet YA, Koller T, Han SW, Bent AF, Ronald PC, Ausubel FM. The Arabidopsis flagellin receptor FLS2 mediates the perception of Xanthomonas Ax21 secreted peptides. Proc Natl Acad Sci U S A. 2011; 108(22):9286-91.

57. Flors V, Ton J, Van Doorn R, Jakab G, García-Agustín P, Mauch-Mani B. Interplay between JA, SA and ABA signalling during basal and induced resistance against Pseudomonas syringae and Alternaria brassicicola. Plant J. 2008;54(1):81-92.

58. Dong X, Hong Z, Chatterjee J, Kim S, Verma DP. Expression of callose synthase genes and its connection with NPR1 signaling pathway during pathogen infection. Planta. 2008:229(1):87-98.

59. Schneider DJ, Collmer A. Studying plant-pathogen interactions in the genomics era: beyond molecular Koch's postulates to systems biology. Annu Rev Phytopathol. 2010;48:457-79.

60. Apostolakos P, Livanos P, Nikolakopoulou TL, Galatis B. Callose implication in stomatal opening and closure in the fern Asplenium nidus. New Phytol. 2010;186(3):623-35.

61. Elias M, Drdova E, Ziak D, BavInka B, Hala M, Cvrckova F, Soukupova H, Zarsky V. The exocyst complex in plants. Cell Biol Int. 2003;27(3):199-201.

62. Munson M, Novick P. The exocyst defrocked, a framework of rods revealed. Nat Struct Mol Biol. 2006;13(7):577.

63. Zhao Y, Liu J, Yang C, Capraro BR, Baumgart T, Bradley RP, Ramakrishnan N, Xu X, Radhakrishnan R, Svitkina T, Guo W. Exo70 generates membrane curvature for morphogenesis and cell migration. Dev Cell. 2013;26(3):26678.

64. Nishimura MT, Stein M, Hou BH, Vogel JP, Edwards H, Somerville SC. Loss of a callose synthase results in salicylic acid-dependent disease resistance. Science. 2003;301:969-72.

65. Luna E, Pastor V, Robert J, Flors V, Mauch-Mani B, Ton J. Callose deposition: a multifaceted plant defense response. Mol Plant Microbe Interact. 2011 24(2):183-93.

66. Kulich I, Vojtíková Z, Sabol P, Ortmannová J, Neděla V, Tihlaříková E, Žárský $\checkmark$. Exocyst subunit EXO7OH4 has a specific role in callose synthase secretion and silica accumulation. Plant Physiol. 2018;176(3):2040-51.

67. Ma SW, Morris VL, Cuppels DA. Characterization of a DNA region required for production of the phytotoxin coronatine by Pseudomonas syringae pv. tomato. Mol Plant Microbe Interact. 1991;4:69-74.

68. Mead PS, Griffin PM. Escherichia coli O157: H7. Lancet. 1998;352(9135):120712.

69. Clark L, Perrett CA, Malt L, Harward C, Humphrey S, Jepson KA, MartinezArgudo I, Carney LJ, La Ragione RM, Humphrey TJ, Jepson MA. Differences in Salmonella enterica serovar Typhimurium strain invasiveness are associated with heterogeneity in SPI-1 gene expression. Microbiol. 2011;157: 2072-83.

70. Katagiri F, Thilmony R, He SY. The Arabidopsis thaliana-Pseudomonas syringae interaction. In: Somerville CR, Meyerowitz EM, editors. The Arabidopsis book. Rockville: American Society of Plant Biologists; 2002 http://www.aspb.org/publications/arabidopsis. Accessed 20 July 2017.

71. Gentleman RC, Carey VJ, Bates DM, Bolstad B, Dettling M, Dudoit S, Ellis B, Gautier L, Ge Y, Gentry J, Hornik K. Bioconductor: open software development for computational biology and bioinformatics. Genome Biol. 2004;5(10):R80

72. Tian T, Liu Y, Yan H, You Q, Yi X, Du Z, Xu W, Su Z. AgriGO v2.0: a GO analysis toolkit for the agricultural community, 2017 update. Nucleic Acids Res. 2017;45(W1):W122-9.

73. Livak KJ, Schmittgen TD. Analysis of relative gene expression data using real-time quantitative PCR and the $2^{-\Delta \Delta C T}$ method. Methods. 2001;25(4): 402-8.

74. Edwards K, Johnstone C, Thompson C. A simple and rapid method for the preparation of plant genomic DNA for PCR analysis. Nucleic Acids Res. 1991; 19(6):1349.

75. Montano J, Melotto M. Stomatal bioassay to characterize bacterialstimulated PTI at the pre-invasion phase of infection. In: Plant pattern recognition receptors. New York: Humana Press; 2017. p. 233-41.
76. Jacob C, Panchal S, Melotto M. Surface inoculation and quantification of Pseudomonas syringae population in the Arabidopsis leaf apoplast. Bio Protoc. 2017;7(5):e2167.

77. Gómez-Gómez L, Felix G, Boller T. A single locus determines sensitivity to bacterial flagellin in Arabidopsis thaliana. Plant J. 1999;18(3):277-84.

78. Keppler LD, Baker CJ, Atkinson MM. Active oxygen production during a bacteria-induced hypersensitive reaction in tobacco suspension cells. Phytopathol. 1989;79(9):974-8.

\section{Publisher's Note}

Springer Nature remains neutral with regard to jurisdictional claims in published maps and institutional affiliations.
Ready to submit your research? Choose BMC and benefit from:

- fast, convenient online submission

- thorough peer review by experienced researchers in your field

- rapid publication on acceptance

- support for research data, including large and complex data types

- gold Open Access which fosters wider collaboration and increased citations

- maximum visibility for your research: over $100 \mathrm{M}$ website views per year

At $\mathrm{BMC}$, research is always in progress.

Learn more biomedcentral.com/submissions 